

\title{
NEW INDOLIZIDINE ALKALOIDS FROM PSYCHROPHILIC YEAST Glyciozyma antarctica PI12
}

\author{
(Alkaloid Indolizidin Baharu daripada Yis Psikrofilik Glyciozyma antarctica PI12) \\ Andi Rifki Rosandy ${ }^{1}$, Wickneswary Nadarajah ${ }^{1}$, Muntaz Abu Bakar ${ }^{1}$, Cheah Yoke Kqueen ${ }^{2}$, \\ Mohd. Ikram Mohd. Said ${ }^{1}$, Laode Muhammad Ramadhan Al Muqarrabun ${ }^{3}$, Rozida Khalid ${ }^{1 *}$ \\ ${ }^{1}$ School of Chemical Science and Food Technology, Faculty of Science and Technology, \\ Universiti Kebangsaan Malaysia, 43600 UKM Bangi, Selangor, Malaysia \\ ${ }^{2}$ Department of Biomedical Sciences, Faculty of Medicine and Health Sciences, \\ Universiti Putra Malaysia, 43400 UPM Serdang, Selangor, Malaysia \\ ${ }^{3}$ Atta-ur-Rahman Institute for Natural Product Discovery, \\ Universiti Teknologi MARA, Puncak Alam Campus, 43200 UiTM Puncak Alam, Selangor, Malaysia \\ *Corresponding author: rozidakhalid@ukm.edu.my
}

Received: 2 March 2016; Accepted: 10 May 2016

\begin{abstract}
Two alkaloid compounds: namely 3-(1-aminoethyl)tetrahydro-1H-pyrrolo[1,2-d][1,2,4]oxadiazine-1,4(3H)-dione (1) and tetrahydro-1H-pyrrolo[2,1-c][1,4]oxazine-1,3(4H)-dione (2) was isolated from Glyciozyma antarctica (PI12), a psychrophilic yeast. The isolated compounds were isolated by Radial Chromatography and Thin Layer Chromatography techniques. The chemical structures were elucidated by Ultraviolet-visible, Infrared, Nuclear Magnetic Resonance and Mass Spectroscopy.
\end{abstract}

Keywords: Glyciozyma antarctica PI12, alkaloids, yeast, psychrophiles

\section{Abstrak}

Dua sebatian alkaloid: 3-(1-aminoetil)tetrahidro-1H-pirrolo[1,2-d][1,2,4]oksadiazin-1,4(3H)-dion (1) and tetrahidro-1Hpirrolo[2,1-c][1,4]oksazin-1,3(4H)-dion (2) telah diasingkan daripada Glyciozyma antarctica PI12, sejenis yis psikrofilik. Sebatian-sebatian telah diasingkan menggunakan teknik Kromatografi Pepejal dan teknik Kromatografi Lapisan Nipis. Strukturstruktur kimia telah dicirikan dengan menggunakan Ultra-Lembayung, Infra-Merah, Resonans Magnet Nukleus dan Spektroskopi Jisim.

Kata kunci: Glyciozyma antarctica PI12, alkaloid, yis, psikrofil

\section{Introduction}

Since the 1960s, bioactive secondary metabolites have been isolated and structurally characterized from eubacteria, archaea, and fungi, microorganisms that have adopted strategies to grow in extreme terrestrial environments. The isolation and bioactivity of these molecules from the following extremophiles has been described such as thermophiles, psychrophiles, acidophiles, alkaliphiles, halophiles, xerophiles, epi- or endophytes, as well as metallotolerant, radioresistant, and unclassifiable microorganisms. Secondary metabolites often play an important role in defense systems of different organisms [1]. Humans use secondary metabolites as medicines, flavorings, and recreational drugs. Microbial secondary metabolites include antibiotics, pigments, toxins, effector of ecological competition and symbiosiss, pheromones, enzyme inhibitors, immunomodulating agents, receptor antagonists and 
agonist, pesticides, antitumor agents and growth promoters of animals and plants. They have a major effect of the health, nutrition and economics of our society [2].

Scientist used the term "psychrophiles" to refer to microorganisms that grow optimally in extremely cold temperatures ranging from $15{ }^{\circ} \mathrm{C}$ or below (e.g. $-20^{\circ} \mathrm{C}$ in sea ice) to a maximum temperature of $20{ }^{\circ} \mathrm{C}$ [3]. Roughly $80 \%$ of our planet's biosphere is at temperatures below $5{ }^{\circ} \mathrm{C}$, which includes most of the world's oceans $(70 \%$ of the Earth's surface), sea ice, Antarctica, parts of North America and Europe, the deep-sea, mountain regions, as well as the mesosphere and stratosphere [4]. Thus, most microorganisms on Earth can be considered to be psychrophiles. Glaciozyma antarctica PI12 (previously known as Leucosporidium antarcticum) is a psychrophilic yeast strain which was isolated from a marine environment in Antarctica [5, 6]. Recently, Turchetti et al. [7] have proposed to reclassify this yeast from Leucosporidium antarcticum to Glyciozyma antarctica. Besides, Glyciozyma antarctica has also been isolated from various locations in Antarctica [8, 9]. Turkiewicz et al. [10] reported that Glyciozyma antarctica 171 has an optimum growth temperature at around $15{ }^{\circ} \mathrm{C}$ and is able to tolerate higher temperatures up to $20{ }^{\circ} \mathrm{C}$. So far, the chemical constituents of this species have not been studied.

This paper describes the isolation and detailed characterization of new derivatives indolizidine alkaloid, 3-(1aminoethyl)tetrahydro-1H-pyrrolo[1,2-d][1,2,4]oxadiazine-1,4(3H)-dione (1) and tetrahydro-1H-pyrrolo[2,1c] $[1,4]$ oxazine-1,3(4H)-dione (2).

\section{Material}

\section{Materials and Methods}

Glyciozyma antarctica PI12 was isolated from sea ice collected in the vicinity of Case Station ( $66^{\circ} 21^{\prime} 25^{\prime \prime}$, $\left.110^{\circ} 37^{\prime} 09^{\prime \prime} \mathrm{E}\right)$, Antarctica. It was identified based on its LSU rRNA and ITS sequences which have been deposited in the GenBank database under accession number JX896855 and JX986956. Glyciozyma antarctica PI12 was routinely cultivated in yeast peptone dextrose (YPD) broth (Difco) medium.

\section{Culturing material}

The culturing of Glyciozyma antarctica PI12 was conducted in collaboration with the Malaysia Genome Institute [11]. The psychrophilic yeast, Glyciozyma antarctica PI12 was originally isolated from Casey sea ice research station located in Antarctica. Initially, $10 \mu \mathrm{L}$ of the Glyciozyma antarctica's glycerols stock was sub-cultured on the YPD agar with $50 \mu \mathrm{g} / \mathrm{mL}$ of Ampicillin and $50 \mu \mathrm{g} / \mathrm{mL}$ Kanamycin at $12{ }^{\circ} \mathrm{C}$ until a single colony is obtained. Next, a starter culture of Glyciozyma antarctica PI12 was prepared by inoculated a single colony of Glyciozyma antarctica PI12 from the agar plate into $10 \mathrm{~mL}$ of YPD medium (50 mL falcon tube) with $50 \mu \mathrm{g} / \mathrm{ml}$ of Ampicillin and 50 $\mu \mathrm{g} / \mathrm{ml}$ Kanamycin. It is then cultured at $12{ }^{\circ} \mathrm{C}$ at $180 \mathrm{rpm}$ until mid-log phase (OD600: 1.0 to 1.8 ) (5 days). Thirdly, a fix amount $\left(10^{6}\right.$ yeast cells $\left./ \mathrm{ml}\right)$ of starter culture was inoculated into $50 \mathrm{~mL}$ of YPD medium (3 flasks of $250 \mathrm{~mL}$ of conical flask was used) with two antibiotics and then cultured at $12{ }^{\circ} \mathrm{C}$ at $180 \mathrm{rpm}$ until mid-log phase (OD600: 1.0 to 1.8) (8 days). After the yeast culture has reached to the mid-log phase (OD600: 1.0 to 1.8), the flask with the yeast culture were exposed separately to $-18{ }^{\circ} \mathrm{C}, 0{ }^{\circ} \mathrm{C}$ and $12{ }^{\circ} \mathrm{C}$ (without shaking) for 48 hours. Finally, the yeast culture was harvested by pouring them to a $50 \mathrm{~mL}$ falcon tube and centrifuged at $3000 \mathrm{rpm}$ for $10 \mathrm{~min}$ at $4{ }^{\circ} \mathrm{C}$. The supernatant and the pellet were collected.

\section{Extraction and isolation}

An amount of $200.7 \mathrm{mg}$ n-butanol extract of G. antarctica PI12 was subjected to Radial Chromatography (RC) with $1 \mathrm{~mm}$ thickness silica gel on a round glass plate and eluted with the mixtures of dichloromethane and methanol with increasing polarity (Starting from DCM/Me-OH, 9.6:0.4). The eluents that showed the same profile on thin layer chromatography (TLC) chromatogram were combined to give three fractions (I-III). Purification of fraction I (1-4) $(29.7 \mathrm{mg})$ was carried out using RC with silica gel plate of $0.5 \mathrm{~mm}$ thickness eluted with DCM and Me-OH (9.2:0.8) in $5 \%$ polarity increment to yield compound $\mathbf{1}(4 \mathrm{mg})$. Purification of fraction II (5-7) (48.8 $\mathrm{mg})$ was conducted utilizing another RC with silica gel plate of $0.5 \mathrm{~mm}$ thickness. Elution with DCM and Me-OH (8.4:1.6) produced compound $\mathbf{2}(12.5 \mathrm{mg})$. 


\section{Compound identification}

Structures of pure compounds were determined based on the spectral data recorded on Shimadzu UV-260 spectrophotometer, Frontier Perkin-Elmer FTIR/NIR spectrophotometer and Bruker NMR $700 \mathrm{MHz}$ Cryo-Probe instrument that included 1-D and 2-D NMR. HR-ESI-MS were recorded by using LCMS-Ultra Performance liquid Chromatography (UPLC), Brand Waters. The isolation was then carried out by radial chromatography using round glass plates of the Merck Kieselgel 60 PF254 (art. no. 7749) and profile was analyzed using smaller pieces from aluminium sheets $20 \times 20 \mathrm{~cm}$ of the Merck TLC silica gel $60 \mathrm{~F} 254$ of $0.25 \mathrm{~mm}$ thickness (art. no. 5554) and then detected under UV light $(254 \mathrm{~nm})$ or by $\mathrm{CeSO}_{4}$ spraying reagent followed by heating.

\section{Characterization study}

\section{Results and Discussion}

3-(1-aminoethyl)tetrahydro-1H-pyrrolo[1,2-d][1,2,4]oxadiazine-1,4(3H)-dione (1) is white amorphous solid. HRESI-MS $[\mathrm{M}+\mathrm{H}]^{+}$at $m / z: 200.2132$ (calc. for $\mathrm{C}_{8} \mathrm{H}_{14} \mathrm{~N}_{3} \mathrm{O}_{3} 200.2151$ ). IR $\bar{v}_{\max }$ (ATR) $\mathrm{cm}^{-1}: 3357,2108,1647,1318$ 1238 and 1087. ${ }^{1} \mathrm{H}$ NMR $(\mathrm{MeOD}, 700 \mathrm{MHz}) \delta_{\mathrm{H}}(\mathrm{ppm})$ and ${ }^{13} \mathrm{C}$ NMR $(\mathrm{MeOD}, 175 \mathrm{MHz}) \delta_{\mathrm{C}}(\mathrm{ppm})$ are tabulated in Table 1.

Tetrahydro-1H-pyrrolo[2,1-c][1,4] oxazine-1,3(4H)-dione (2) is clear crystal. HR-ESI-MS $[\mathrm{M}+\mathrm{H}]^{+}$at $\mathrm{m} / \mathrm{z}: 156.1508$ (calc. for $\mathrm{C}_{7} \mathrm{H}_{10} \mathrm{NO}_{3} 156.1592$ ). IR $\bar{v}_{\max }$ (ATR) cm ${ }^{-1}: 3191,1640,1453,1332,1294-1217,1110,1004,922-764 .{ }^{1} \mathrm{H}$ NMR $(\mathrm{MeOD}, 700 \mathrm{MHz}) \delta_{\mathrm{H}}(\mathrm{ppm})$ and ${ }^{13} \mathrm{C} \mathrm{NMR}(\mathrm{MeOD}, 175 \mathrm{MHz}) \delta_{\mathrm{C}}(\mathrm{ppm})$ are tabulated in Table 2.

The structure (Figure 1) elucidation of the compounds were conducted using several spectroscopic methods including mass spectrometer, UV, FT-IR, NMR 1D and 2D (HMQC, HMBC, COSY, and NOESY), and by comparison with reported data.

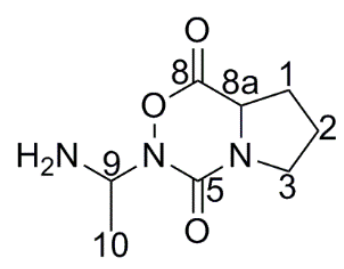

1

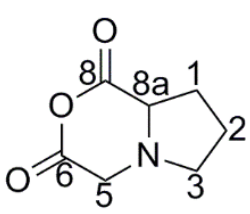

2

Figure 1. Chemical structures of isolated compounds $\mathbf{1}$ and $\mathbf{2}$

\section{3-(1-aminoethyl)tetrahydro-1H-pyrrolo[1,2-d][1,2,4]oxadiazine-1,4(3H)-dione (1)}

Compound 1 was isolated as white amorphous. The molecular formula is $\mathrm{C}_{8} \mathrm{H}_{13} \mathrm{~N}_{3} \mathrm{O}_{3}$, generated using HR-ESI-MS $[\mathrm{M}+\mathrm{H}]^{+}$ion at $m / z: 200.2132$ (calc. for $\mathrm{C}_{8} \mathrm{H}_{14} \mathrm{~N}_{3} \mathrm{O}_{3}$ 200.2151). The FTIR spectral data displays broad absorbance peak at 3357 representing primary amine $\left(-\mathrm{NH}_{2}\right)$, overtone (weak) at $2108 \mathrm{~cm}^{-1}$ and tertiary amine at $1318 \mathrm{~cm}^{-1}$, 2985 and $2881 \mathrm{~cm}^{-1}$ representing the C-H (aliphatic cyclic). The presence of carbonyl group is characterized by absorbance bands, i.e. $\mathrm{C}=\mathrm{O}$ stretch at $1647 \mathrm{~cm}^{-1}$ indicated that the carbonyl group linked with the tertiary amide. Furthermore, that tertiary amide is characterized by absorbance at 1318 and $1087 \mathrm{~cm}^{-1}$.

The ${ }^{13} \mathrm{C}$ spectrum reveals that the compound contains 8 carbons consisting of one methyl, three methylenes, two methines and two quaternary carbons. The most highly deshielded signals at $\delta_{\mathrm{C}} 170.1(\mathrm{C}-8)$ and $165.0(\mathrm{C}-5)$ were attributed to carbonyl group linked with tertiary amide and another one was from ester group. Two signal of methines at $\delta_{\mathrm{C}} 58.8(\mathrm{C}-8 \mathrm{a})$ provide information of the presence of an 1H-pyrrolo carbon that linked with a quarternary carbon C-8 and a tertiary amine, while the other one (C-9) linked with an equivalent proton methyl and a primary amine. Three shielded carbons $(\mathrm{C}-1, \mathrm{C}-2$ and $\mathrm{C}-3)$ represent the existence of a pyrrolidine framework in the molecule. The Double Bond Equivalent (DBE) value of $\mathrm{C}_{8} \mathrm{H}_{13} \mathrm{~N}_{3} \mathrm{O}_{3}$ is 4, indicating that the compound consists of two double bonds as carbonyls group and two ring of derivative indolizidine alkaloid as main structure. Meanwhile, 10 proton signals representing 13 protons appeared in the ${ }^{1} \mathrm{H}-\mathrm{NMR}$ spectrum. Ten of the signals came 
from the four signals, one each from a methyl group at $\mathrm{H}-10(1.45, d, J=7)$ bind with a methine proton at $\mathrm{H}-9\left(\delta_{\mathrm{H}}\right.$ 4.05) are quartet, while a primary amine bind this methine at C-9. Furthermore, the other methine at $\left(\delta_{\mathrm{H}} 4.26\right)$ is triplet, indicating it is adjacent to a methylene at C-1. Meanwhile, the other two saturated methylenes form pyrrolidine skeleton in the molecule.

The structure is confirmed using 2D NMR (Table 1). The HMBC experiment shows H-8a has correlation with C-1, and $\mathrm{H}-1$ with $\mathrm{C}-2$ and $\mathrm{C}-3$. Proton methine $\mathrm{H}-9$ has correlations with $\mathrm{C}-10$, while all methine protons have correlation with the carbonyl carbons, confirming the position of C-5 and C-8. In COSY spectrum, H-2 shows strong coupling with H-1 and H-3, while H-9 show strong coupling with methyl proton at H-10 (Fig. 2 (a)).

Table 1. NMR data of 3-(1-aminoethyl)tetrahydro-1H-pyrrolo[1,2-d][1,2,4]oxadiazine-1,4(3H)-dione (1)

\begin{tabular}{|c|c|c|c|c|c|}
\hline No & $\begin{array}{l}\text { APT } \\
(\mathbf{p p m})\end{array}$ & $\begin{array}{l}\text { HSQC } \\
\text { (mult., } J \text { in } \mathrm{Hz}) \Sigma \mathrm{H}\end{array}$ & HМBC & $\begin{array}{l}\text { H-H } \\
\text { Cosy }\end{array}$ & $\begin{array}{l}\text { H-H } \\
\text { Noesy }\end{array}$ \\
\hline 1 & 28.2 & $\begin{array}{l}2.35(\mathrm{~m}) \mathrm{ax} 1 \mathrm{H} \\
1.97(\mathrm{~m}) \text { eq } 1 \mathrm{H}\end{array}$ & $\begin{array}{l}\text { C-8a; C-3 } \\
\text { C-8a; C-3; C-2 }\end{array}$ & H-8a; H-2 & H-2eq; H-3ax; H8a $($ ax) \\
\hline 2 & 21.8 & $\begin{array}{l}2.04(\mathrm{~m}) \mathrm{ax} 1 \mathrm{H} \\
1.95(\mathrm{~m}) \mathrm{eq} 1 \mathrm{H}\end{array}$ & $\begin{array}{l}\mathrm{C}-1 \\
\mathrm{C}-1 ; \mathrm{C}-3 ; \mathrm{C}-8 \mathrm{a}\end{array}$ & $\mathrm{H}-1 ; \mathrm{H}-3$ & $\mathrm{H}-1 \mathrm{eq} ; \mathrm{H} 8 \mathrm{a}_{(\mathrm{ax})}$ \\
\hline 3 & 44.8 & $\begin{array}{l}3.62(m) \text { ax } 1 \mathrm{H} \\
3.51(m) \text { eq } 1 \mathrm{H}\end{array}$ & $\begin{array}{l}\mathrm{C}-2 \\
\mathrm{C}-1 ; \mathrm{C}-2\end{array}$ & $\begin{array}{l}\mathrm{H}-2 \\
\mathrm{H}-2\end{array}$ & H-2eq: H-1ax \\
\hline 5 & 165.0 & - & - & - & - \\
\hline 8 & 170.1 & - & - & - & - \\
\hline $8 a$ & 58.8 & $4.26(t, J=7) \mathrm{ax} 1 \mathrm{H}$ & $\mathrm{C}-1 ; \mathrm{C}-8$ & $\mathrm{H}-1$ & H-1 eq; H-2ax \\
\hline 9 & 50.4 & $4.05(\Psi m)$ eq $1 \mathrm{H}$ & $\mathrm{C}-1 ; \mathrm{C}-5 ; \mathrm{C}-10$ & $\mathrm{H}-10$ & H-10eq \\
\hline 10 & 18.6 & $1.45(d, J=7)$ eq $3 \mathrm{H}$ & C-5; C-8; C-9 & H-9 & $\mathrm{H}-1 \mathrm{ax} ; 9-\mathrm{NH}_{2} ; \mathrm{H}-9 \mathrm{eq}$ \\
\hline 9- $\mathrm{NH}_{2}$ & - & $4.60(b r-s)$ eq $2 \mathrm{H}$ & - & - & - \\
\hline
\end{tabular}

According to Silverstein et al. [12], the vicinal coupling constant between an axial $\mathrm{H}$ with another axial $\mathrm{H}$ ranges from 6 to $10 \mathrm{~Hz}$, while the vicinal coupling constant between an equatorial $\mathrm{H}$ with an axial $\mathrm{H}$ is around 0 to $5 \mathrm{~Hz}$. The relative configuration of the sole chiral carbon (C-8a) was observed using Nuclear Overhauser Effect Spectroscopy (NOESY) experiment which describes the $\mathrm{H}-\mathrm{H}$ correlation through space (Figure 2(b)). From the NOESY spectrum, it was observed that carbon methine at $\mathrm{C}-8 \mathrm{a}$ in pyrrolidine skeleton bind one proton in the axial position with coupling constant value $J=7 \mathrm{~Hz}$. Since $\mathrm{H}-8 \mathrm{a}_{(\mathrm{ax})}$ generates cross peak with $\mathrm{H}-2_{\mathrm{ax}}$, which means they are in the same orientation. According to Karplus curve, if a proton has correlation with another proton in the same orientation, indicating they are in the eclipse position (dihedral angel of $0^{\circ}$ ). Then, methyl group at $\mathrm{C}-10$ binds three geminal protons, has doublet splitting and $J$ value is $7 \mathrm{~Hz}$, indicating that $\mathrm{H}-10$ is in axial position/eclipse position (dihedral angel of $0^{\circ}$ ) toward H-9.

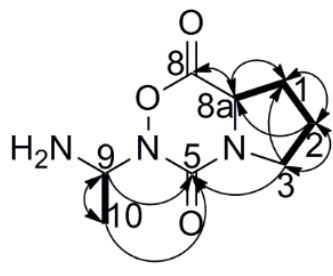

(a)

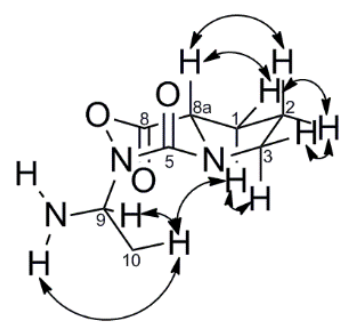

(b)

Figure 2. Compound 1; 2D correlation NMR; (a) HMBC $(\rightarrow)$ \& COSY $(-)$, (b) NOESY 
Tetrahydro-1H-pyrrolo[2,1-c][1,4]oxazine-1,3(4H)-dione (2)

Compound 2 was isolated as a clear crystal. The molecular formula $\mathrm{C}_{7} \mathrm{H}_{9} \mathrm{NO}_{3}$ was generated using HR-ESI-MS [M $+\mathrm{H}]^{+}$ion at $m / z 156.1532$ (calc. for $\mathrm{C}_{7} \mathrm{H}_{10} \mathrm{NO}_{3}$ 156.1592). The UV spectrum indicated that there was no conjugated double bond in the molecule; this was deducted by the presence of only one absorbance band at $203 \mathrm{~nm}$. The FT-IR spectral data presence of carbonyl group was indicated by a strong stretching band of $\mathrm{C}=\mathrm{O}$ at $1640 \mathrm{~cm}^{-1}$ and the vibration band at $1004 \mathrm{~cm}^{-1}$ indicated the $\mathrm{C}-\mathrm{O}$ bending representing an ester group. The $\mathrm{C}-\mathrm{C}(=\mathrm{O})-\mathrm{O}$ asymmetrical stretching vibration was indicated by absorbance band at $1294 \mathrm{~cm}^{-1}$. The $\mathrm{Csp}^{3}-\mathrm{H}$ stretching band appeared at 2956$2889 \mathrm{~cm}^{-1}$, while absorption bands at $1453 \mathrm{~cm}^{-1}$ indicated the asymmetrical bending vibrations of Csp $-\mathrm{H}$ of the methylene groups. A tertiary amine was detected in this compound at $1332 \mathrm{~cm}^{-1}$.

The presence of functional groups is supported by NMR analysis of $1-\mathrm{D}\left({ }^{1} \mathrm{H}\right.$ and APT experiment of $\left.{ }^{13} \mathrm{C}-\mathrm{NMR}\right)$ and 2-D (HSQC, HMBC, H-H COSY and H-H NOESY) data. The APT experiment data showed the presence of 7 carbon signals representing two quaternary, one methine and four methylenes carbons. The DBE value of four indicated that this compound was an indolizidine alkaloid containing two double bonds. The most deshielded carbons at $\delta_{\mathrm{C}} 170.5$ and $165.0 \mathrm{ppm}$ was indicated as an asymmetrical carbonyl group. Three saturated nonequivalent methylenes signals at $\delta_{\mathrm{C}} 27.9(\mathrm{C}-1), 21.9(\mathrm{C}-2)$ and $44.9(\mathrm{C}-3)$ are attributed to pyrrolidine ring in this molecule, while another methylene signal at $\delta_{\mathrm{C}} 45.5 \mathrm{ppm}$ (C-5) indicated the presence of a methylene existed between carbonyl and tertiary amine. Furthermore, methine carbon at $\delta_{\mathrm{C}} 58.4 \mathrm{ppm}(\mathrm{C}-8 \mathrm{a})$ is the specific of methine signal of indolizidine alkaloid for this molecule. Meanwhile, 9 proton signals representing 9 protons appeared in the ${ }^{1} \mathrm{H}-\mathrm{NMR}$ spectrum as shown in Table 2. Eight of the signals came from the three methylenes proton, one each from isolated methylene at H-5 binds carbonyl and tertiary amine and another three non-equivalent methylenes at $\mathrm{H}-1, \mathrm{H}-$ 2 and $\mathrm{H}-3$, forming a basic pyrrolidine ring. An aminated methine proton, $\mathrm{H}-8 \mathrm{a}_{(\mathrm{ax})}\left(\delta_{\mathrm{H}} 4.25, \Psi t, J=7.0\right)$ are pseudo doublet, indicating that $\mathrm{C}-8 \mathrm{a}$ is adjacent to a methylene group (C-1).

The structure of 2 was confirmed using 2D NMR including HMBC, COSY and NOESY. The HMBC spectrum revealed a strong correlation between methine $(\mathrm{C}-8 \mathrm{a})$ and the carbonyl carbon $(\mathrm{C}-8)$ as well as between $\mathrm{C}-8 \mathrm{a}$ and saturated non-equivalent methylene group (C-1). This indicated that the methine group as chiral position. The correlations between $\mathrm{H}-5$ and C-8a as well as between $\mathrm{H}-5$ and C- 6 confirmed the position of the isolated methylene in the molecule as described in Figure 2(a). NOESY spectrum revealed correlation between $\mathrm{H}-8 \mathrm{a}_{(\mathrm{ax})}$ and H-1ax as well as between $\mathrm{H}-8 \mathrm{a}_{(\mathrm{ax})}$ and $\mathrm{H}-2 \mathrm{ax}$ confirming the position of the chiral group in the molecule (Figure 3(b)).

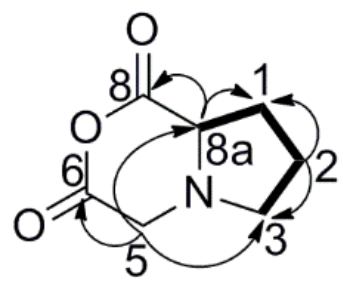

(a)



(b)

Figure 3. Compound 2; 2D correlation NMR; (a) HMBC $(\rightarrow) \&$ COSY (-), (b) NOESY 
Table 2. NMR data of tetrahydro-1H-pyrrolo[2,1-c][1,4]oxazine-1,3(4H)-dione (2)

\begin{tabular}{|c|c|c|c|c|c|}
\hline No & $\begin{array}{l}{ }_{(\mathbf{p p m}}^{13} \mathrm{C} \\
\text { (ppm }\end{array}$ & $\begin{array}{l}\text { HSQC } \\
\text { (mult., } J \text { in Hz, } \Sigma \text { } \Sigma \text { H }\end{array}$ & HMBC & $\begin{array}{l}\text { H-H } \\
\text { Cosy }\end{array}$ & $\begin{array}{l}\text { H-H } \\
\text { Noesy }\end{array}$ \\
\hline 1 & 27.9 & $\begin{array}{l}2.34(t, J=7) \text { ax } 1 \mathrm{H} \\
1.99(t, J=7) \text { eq } 1 \mathrm{H}\end{array}$ & $\begin{array}{l}\text { C-2; C-3; C-8a } \\
\text { C-2; C-8a; C-8 }\end{array}$ & $\begin{array}{l}\mathrm{H}-8 \mathrm{a}_{(\mathrm{ax})} \\
\mathrm{H}-3\end{array}$ & $\begin{array}{l}\text { H-3ax } \\
\text { H-2eq; H-8a }(\text { ax) }\end{array}$ \\
\hline 2 & 21.9 & $\begin{array}{l}2.04(m) \text { ax } 1 \mathrm{H} \\
1.95(m) \text { eq } 1 \mathrm{H}\end{array}$ & $\begin{array}{l}\text { C-1; C-3; C-8a; C-8 } \\
\text { C-1; C-3; C-8a }\end{array}$ & $\begin{array}{l}\mathrm{H}-3 \\
\mathrm{H}-3\end{array}$ & $\begin{array}{l}\mathrm{H}-8 \mathrm{a}_{(\mathrm{ax})} \\
\mathrm{H}-1 \text { eq; } \mathrm{H}-3 \mathrm{eq}\end{array}$ \\
\hline 3 & 44.9 & $\begin{array}{l}3.57(\Psi t, J=7) \text { ax } 1 \mathrm{H} \\
3.54(\Psi t, J=7) \text { eq } 1 \mathrm{H}\end{array}$ & $\begin{array}{l}\text { C- } 2 ; C-1 ; C-8 a ; C-6 \\
\text { C- } 2 ; C-1 ; C-8 a ; C-6\end{array}$ & $\begin{array}{l}\mathrm{H}-2 \\
\mathrm{H}-1\end{array}$ & $\begin{array}{l}\text { H-1ax; H-5eq: } H-8 a_{(a x)} \\
\text { H-2eq }\end{array}$ \\
\hline 5 & 45.5 & $\begin{array}{l}4.13(\Psi d, J=16.8) \mathrm{ax} 1 \mathrm{H} \\
3,77(d, J=16.8) \text { eq } 1 \mathrm{H}\end{array}$ & $\begin{array}{l}\text { C-8a; C-6; C-3; C-8 } \\
\text { C-8a; C-6; C-3; C-8 }\end{array}$ & $\begin{array}{l}\text { H-5 } \\
\text { H-5 }\end{array}$ & H-3ax \\
\hline 6 & 165.0 & - & - & - & \\
\hline 8 & 170.5 & - & - & - & \\
\hline $8 \mathrm{a}$ & 58.4 & $4.25(\Psi t, J=7.0) \mathrm{ax} 1 \mathrm{H}$ & $\mathrm{C}-1 ; \mathrm{C}-8$ & H-1; H-1 & H-1eq; H-2ax; H-3ax \\
\hline
\end{tabular}

\section{Conclusion}

The phytochemical investigation of the psycrophilic yeast Glyciozyma antarctica PI12 resulted in the isolation of new derivatives indolizidine alkaloid named 3-(1-aminoethyl)tetrahydro-1H-pyrrolo[1,2-d][1,2,4]oxadiazine1,4(3H)-dione (1) and tetrahydro-1H-pyrrolo[2,1-c][1,4]oxazine-1,3(4H)-dione (2). To the best of our knowledge, this is the first report for both of compounds from this species. In addition, these compounds contributed to the small yet expending database of secondary metabolites from psychrophiles.

\section{Acknowledgement}

Authors would like to thank the School of Chemical Sciences and Food Technology, Faculty of Science and Technology, Universiti Kebangsaan Malaysia (UKM); Malaysia Genome Institute for providing research facilities and also would like to express our gratitude to the LPDP (Indonesia Endowment Fund for Education) and the Ministry of Science and Technology for financial support through research grants of 02-05-20-SF0007 and GGPM2013-076, respectively.

\section{References}

1. Stamp, N. (2003). Out of the quagmire of plant defense hypotheses. The Quarterly Review of Biology, 78: 23 55.

2. Davati, N. and Najafi, M. B. H. (2013). Overproduction strategies for microbial secondary metabolites: A review. International Journal of Life Science \& Pharma Research, 3: 23 - 37.

3. Morita, R.Y. (1975). Psychrophilic bacteria. Bacteriological Reviews, 39: 144 - 167.

4. De Maayer, P., Anderson, D., Cary, C. and Cowan, D. A. (2014). Some like it cold: Understanding the survival strategies of psychrophiles. EMBO Reports, 15: $508-517$.

5. Fell, J. W., Statzell, A., Hunter, I. L. and Phaff, H. J. (1969). Leucosporidium genus, the heterobasidiomycetous stage of several yeasts of the genus Candida. Antonie van Leeuwenhoek, 35: 433 - 462.

6. Fell, J. W. (1974). Heterobasidiomycetous yeasts Leucosporidium and Rhodosporidium. Their systematics and sexual incompatibility systems. Transactions of the Mycological Society of Japan, 15: 316 - 323.

7. Turchetti, B., Thomas-Hall, S. R., Connell, L. B., Branda, E., Buzzini, P., Theelen, B., Müller, W. H. and Boekhout, T. (2011). Psychrophilic yeasts from antarctica and european glaciers: description of Glaciozyma genus, Glaciozyma martinii species and Glaciozyma watsonii species. Extremophiles, 15: 573 - 586.

8. Donachie, S. P. (1995). Ecophysiological description of marine bacteria from Admiralty Bay (Antarctica), and the digestive tracts of selected Euphausiidae. Ph. D. Thesis. Department of Antarctic Biology, Polish Academy of Sciences, Warsaw. 
9. Connell, L., Redman, R., Craig, S., Scorzetti, G., Iszard, M. and Rodriguez, R. (2008). Diversity of soil yeasts isolated from South Victoria land, Antarctica. Microbial Ecology, 56: 448 - 459.

10. Turkiewicz, M., Pazgier, M., Donachie, S. P. and Kalinowska, H. (2005). Invertase and $\alpha$-glucosidase production by the endemic Antarctic marine yeast Leucosporidium antarcticum. Polish Polar Research, 26: $125-136$.

11. Boo, S. Y., Wong, M. V. L., Rodrigues, K. F., Najimudin, N., Murad, A. M. A. and Mahadi, N. M. (2013). Thermal stress responses in Antarctic yeast, Glaciozyma antarctica PI12, characterized by real-time quantitative PCR. Polar Biology, 36: 381 - 389.

12. Silverstein, R. M., Webster, F. X. and Kiemle, D. J. (2005). Spectrometric identification of organic compounds. 7th ed. Hoboken, NJ: Wiley. 